\title{
Inclusion and Moral Competence. Hypotheses about Two Closely Related Tasks of the School ${ }^{1}$
}

\author{
Martina Reinicke \\ (Berufliches Schulzentrum Döbeln-Mittweida,m.reinicke@primacom.net)
}

\section{Historical Overview of Inclusion Efforts}

The following short overview of the history of inclusion does not claim to be complete and focuses solely on the relationship between inclusion and morality.

The first endeavours to educate children both with and without disabilities go back to the 17th century, when Johann Amos Comenius represented the approach 'Teach everybody everything as a whole!' in his book Didactica magna.

During years of growth, the whole youth, of both genders, without neglecting anyone, should be instructed in the sciences, trained in the virtues and fulfilled in piety-in such a comprehensible manner in all things of the present and future life (...) extensively, cheerfully and thoroughly (Comenius, 52).

Comenius also was one of the first to stress the need for moral education (in sense of "mores" and "religio" (Comenius) in schools. Moreover, he gives the following thesis: "The seeds of virtue lie in nature of man from birth." He justifies this thesis as follows: "(...) each human enjoys harmony" and "this itself is nothing but harmony in the interior as in the exterior" (Comenius, 41).

In course of enlightenment, Marquis de Condorcet also calls for generally accessible educational institutions for men and women and for blacks and whites. Moreover, Condorcet points out the tense relation between the universal claim to equality and the need for differentiation:

Upbringing and education [should be] so equal and so general, but there again so for each individually as complete as possible (Feuser 2001,2).

Diderot links the attitudes of humans and their morals with the term of disability in his essay 'Letter on the Blind for the Use of Those who See' from 1749:

\footnotetext{
1 Paper presented at the International Conference "Moral Competence: A brand new research topic", September 29th-30th, 2017, at Adam Mickiewicz University, Poznań, Poland.
} 
The state of our organs and our senses has a great influence on our metaphysics and morality (Diderot 1916, 78).

According to Pöhlmann, this 'direct linking of moral norms with sensuous perception' leads to a relativization of ideas of morality (Pöhlmann 2016, 161).

Diderot's friend Rousseau-as well as Pestalozzi and, later, Wilhelm von Humboldt-also supports the ideal of complete education. In the course of industrialization, Humboldt argues that the weak and the poor must also be included in the educational process:

What is demanded of a nation, an age, of the whole human race, if one should give them his respect and admiration? It is demanded that education, wisdom, and virtue should be so powerful and general as possible that they should be able to increase his inner value so much that the concept of humankind (...) would be achieved great and worthy content (Humboldt 1960, 236).

According to Humboldt, comprehensive and holistic education thus requires and promotes moral behavior. Elsewhere, he justifies this as follows:

No matter how good he is, every human bears actually an even better human in himself, who is his much more real self (Humboldt 1822).

Furthermore, Comenius and Pestalozzi, as well as Jean Paul (1763-1825) and Friedrich Fröbel (1782-1852), emphasize the importance of such comprehensive education from early childhood. At the beginning of the 20th century, the Italian doctor and pedagogue Maria Montessori took up this idea and evolved the healing pedagogical approach named after her. The German scientist Jacob Muth spoke in the 1970s of the human right to education and the right to a joint education of the disabled and the non-disabled from early childhood. According to Muth, communication with the other is fundamental in this context.

How else should non-disabled people be able in everyday life and from early childhood to correct their prior knowledge and prejudices and to be tactful to disabled people? And how should differently disabled people gain the strength to cope with tactlessness of the non-disabled without communicating with them from the early age? For every human, even for the handicapped, the acceptance of himself is not to win in a space without communication, but always in the be-together with others, in handling fellow humans, in respect for the dignity of the other (Muth 1986).

In his remarks, Muth highlights the necessity of individualization of learning requirements and the necessity of constant discussion on a moral basis, because exclusion and stigmatization are always immoral: 
Integration is indivisible. That means it applies to all. It is not possible to aim for similarities of young people in general school, and exclude simultaneously a part (Muth 1986).

This approach also is often referred to as the German hour of birth of integration. Thereupon, Germany opened itself up to international research.

In the mid-1990s, the national scientific discourse on early-childhood development and education began, which was soon supplemented by a political debate. Almost at the same time, inclusion become the subject of international and national political debate. The Salamanca Declaration of the UNESCO was adopted in 1994. Tony Booth and Mel Ainscow published the 'Index for Inclusion' in 2002 (Booth \& Ainscow 2002). Furthermore, the 'Convention on Rights of people with disabilities' was adopted in 2008. As early as 2009, Germany ratified the UN Disability Equality Convention and the "Index for Inclusion" was translated into German by Boban \& Hinz (Booth \& Ainscow 2003). Since then, the Index has been translated into several languages.

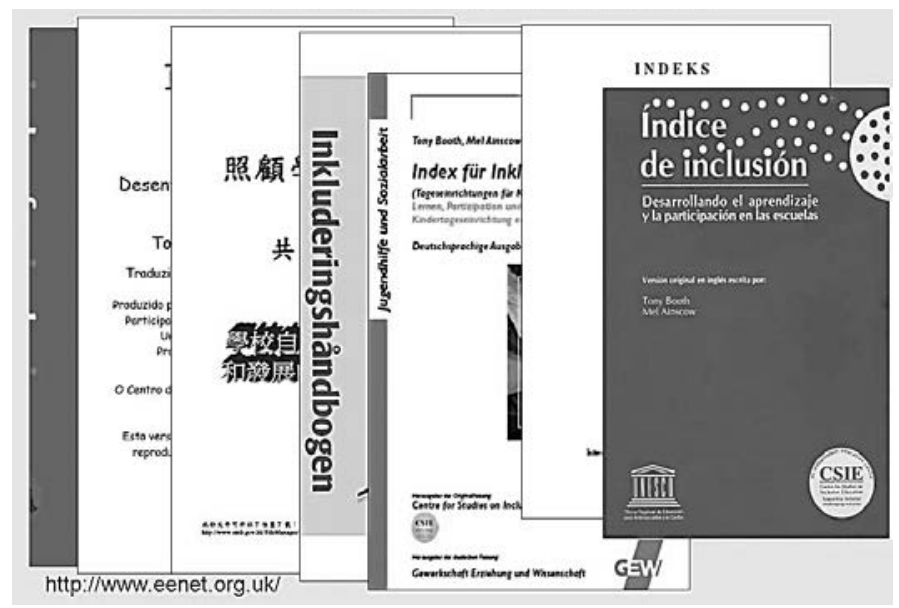

Figure 1: Index for Inclusion in several languages (Boban, Hinz 2012)

In 2015, UNESCO, together with UNICEF, the World Bank, and other organizations organized the World Education Forum in Incheon, Republic of Korea. The outcome of this meeting was the Incheon declaration-also entitled as Education 4.0 or Education 2030. Over 120 ministers for education from around the world adopted the Incheon Declaration. The declaration, which sets out a new vision for education for the next 15 years, says: "Ensure inclusive and equitable quality education and promote lifelong learning opportunities for all" (Education 2030_Framework for Action 2016, 7)

This is an ambitious goal. But what is happening currently in scientific research in terms of inclusion? What does inclusion look like in practice? 


\section{Current State of Inclusion Research}

In my opinion, the current inclusion debate and consequently inclusion itself lack an important aspect-the debate on morality and on the role of morality in inclusion. To implement the mentioned Incheon declaration as well as inclusion in general, the introduction of moral education in schools is required. I try to prove this in this article.

Hans Wocken, a popular German scientist of integration pointed out that:

'The scientific discourse about integration and inclusion' is colourful and controversial; it's like a Babylonian language confusion' (Wocken 2009, 2).

This observation made by Wocken applies both to the scientific discourse regarding the concept of inclusion in general and to the theories about inclusion. The reasons for such a complexity of discourse about inclusion are manifold. In the meantime, the different disciplines deal with theme of 'inclusion'. As a result of the developments outlined above, some scientists have pragmatically replaced the notion of 'integration' with the term 'inclusion'. Non-scientists as well as some scientists use the term inclusion in an inflationary manner, similar to a fashion concept. In addition, there are inaccuracies regarding translation of texts from English or American into German.

Therefore, it is almost impossible to determine trends or directions. Nevertheless, at this point, I attempt to sketch the state of research or developments in regard to inclusion/integration.

\section{Scientific lines}

In my view, three scientific lines can be identified:

Inclusion As a Process of Progressive Adjustment with the Goal To Create Equal Conditions for All (Approach of Increasing Equality).

Some scientists understand inclusion as a process of adjustment. The focus of this approach is on equal participation. Inclusion is understood as a goal that could be achieved one day. The representatives of this direction assume that someday all students will face equitable conditions.

Alois Bürli (1977) developed a stepwise model for the development of special education: exclusion, separation, integration, and inclusion. Alfred Wolfgang Sander understands inclusion as 'Phase 4' of this process of development. According to Sander (2006), this phase

(...) differs quantitatively and, above all, qualitatively from the previous phases, as long as inclusion is understood as an optimized and extensively extended integration (Sander 2006, 3).

"Therefore, inclusion can be understood as a model of integration which has been thought through till the end," Otto Speck $(2010,14)$ emphasizes. 


\section{Inclusion As 18/09/2018 Approach, Which Is in Accordance with the Real Conditions of Heterogeneity (Approach of Increasing Diversity)}

Another scientific approach understands inclusion as a maximization of diversity. Scientists, who represent this position also understand inclusion as a goal. Important representatives of this approach are Andreas Hinz, Timm Alberts, Georg Feuser and Ulf Preuss-Lausitz. They understand diversity as normality (Albers 2014, 32), which requires an adaptation of both the schoolsystem as well as the system of value (Feuser 2013,3). Inclusion is understood as an educational policy goal (Preuss-Lausitz 2011, 30), which meets the human right to individual development and social participation, regardless of personal requirement of support (Antor \& Bleidick 2006, 89).

\section{Inclusion As Dynamic Balance between Equality and Diveristy ('Theory of Integrative Process')}

But the Frankfurt Group of Deppe-Wolfinger, Klein, Prengel, Reiser, Hinz, and others assume that inclusion is a dynamic process between the described goals and between equality and diversity. These scientists consider integrative processes to be characterized by a dynamic balance of equality and diversity. The Frankfurter Group continues in the tradition of Piaget, with the "theory of integrative processes" (Wocken 2009, 10).

In sum, regarding above statements, and in accordance with Reiner Geißler (2004),

I would define inclusion as a continuous and dynamic process, where everyone is equally participating on the one hand, and on the other hand, there is a claim to diversity. ${ }^{2}$

\section{Empirical Research}

\section{Effects of inclusive education}

The empirical research of inclusion particularly focuses on the effects of inclusion in different types of schools, especially in primary schools and particularly on students with learning problems. Other impairments such as blindness, multiple or mental disability, socioeconomic peculiarities, and cultural background have seldom been researched (Lindemann 2016). Nevertheless, the effects of the joint teaching of children both with and without disabilities were examined. In summary, it is indisputable that the joint teaching of disabled and non-disabled children has good learning effects for both groups. But the social behavior does not always improve. Although students work and learn together, disadvantaged students often still remain excluded (Ellinger \&

2 Working definition by Martina Reinicke 
Stein 2012; Huber \& Wilbert 2012). It is particularly noticeable that a lot of students with special needs have social acceptance problems as well as problems with their academic self-concept. There are bullying problems in schools and classes even though disabled and nondisabled students know each other.

\begin{tabular}{|c|c|c|c|c|}
\hline & $\begin{array}{l}\text { Learning } \\
\text { development }\end{array}$ & $\begin{array}{l}\text { Social } \\
\text { behaviour }\end{array}$ & $\begin{array}{l}\text { Social } \\
\text { acceptance }\end{array}$ & $\begin{array}{l}\text { Self- } \\
\text { concept }\end{array}$ \\
\hline $\begin{array}{l}\text { Students } \\
\text { without } \\
\text { disabilities }\end{array}$ & $\begin{array}{l}\text { no } \\
\text { disadvantages }\end{array}$ & $\begin{array}{l}\text { positive } \\
\text { classroom } \\
\text { climate }\end{array}$ & $?$ & $?$ \\
\hline $\begin{array}{l}\text { Students } \\
\text { with } \\
\text { disabilities }\end{array}$ & $\begin{array}{l}\text { learning } \\
\text { success } \\
\text { high dropout } \\
\text { rate }\end{array}$ & $\begin{array}{l}\text { good if single - } \\
\text { integration } \\
\text { unclear if high } \\
\text { heterogeneity }\end{array}$ & $\begin{array}{l}2-3 x \text { more } \\
\text { mobbing risk } \\
\text { mobbing } \\
\text { actions } \\
50 \%\end{array}$ & $\begin{array}{l}\text { in-conspicuous } \\
\text { negative } \\
\text { academic self } \\
\text { concept }\end{array}$ \\
\hline
\end{tabular}

Table 1: Effects of inclusion (Dumke \& Schäfer 1993; Feyerer 1998; Myklbust, 2002; Visser et al. 2010; Huber 2008; Sauer 2008)

\section{Conditions for success}

Despite these problems, a number of conditions for the success of inclusion have been developed. In this context, most scientists are convinced that inclusion basically depends on the attitudes of teachers and parents towards inclusion. These conditions for the success of inclusion were derived from several nationalities (Germany) among others Hennemann, Wilbert and Hillenbrand (2014) and Huber (2011) as well as international research results, for example Ferguson's (2008) and Dyson's (2004).

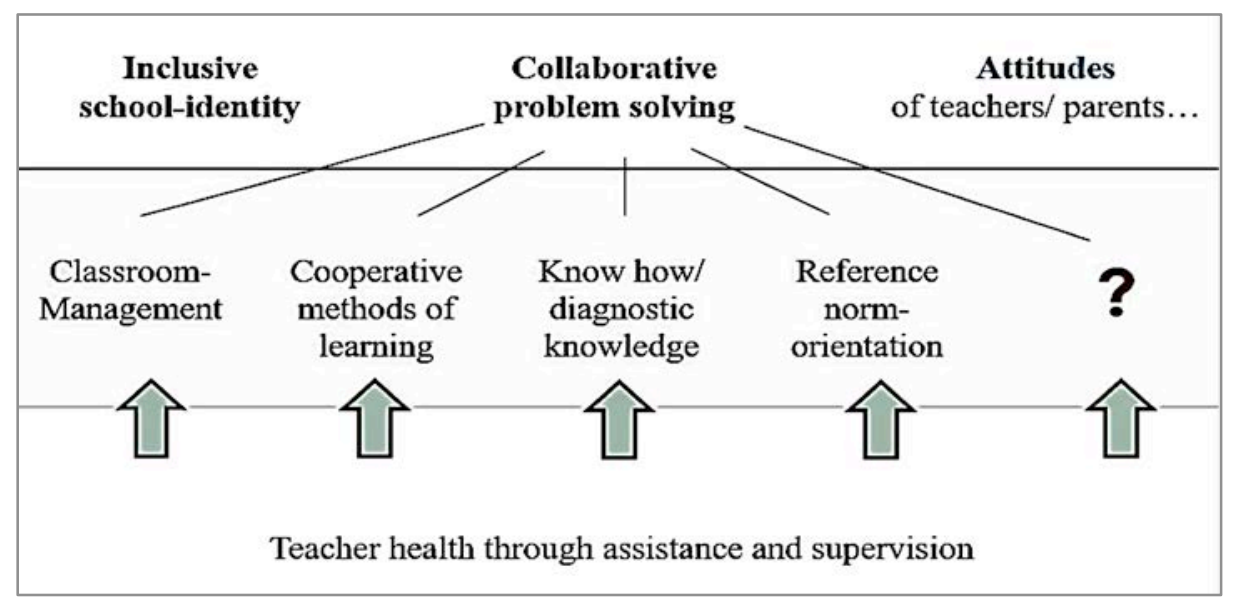

Figure 2: Conditions for success of inclusion by Huber 


\section{Attitude research}

Attitudes are regarded as the key factor of successful inclusion.

As many international studies have already confirmed, a positive attitude towards inclusion is a prerequisite for a transformation of the school system towards inclusion. Against the will and conviction of the individual, this path cannot be successful (Hennemann, Wilbert \& Hillenbrand 2014, 53).

However, the aforementioned observation regarding scientific discourse about integration and inclusion by Wocken is also my observation in regard to attitude research:

It is assumed that there are currently around 200 definitions of the term attitude and just as many theories (Six 2000, 3914).

Amongst many scientists, the opinion prevails that an attitude comprises either one (Fishbein \& Ajzen 1975), two (Stroebe 1980), or three (Triandis 1975) components: an affective and/or cognitive and/or behavioral component (see also Güttler 1996, Hartung 2000).

But in 1985, Georg Lind emphasized that behavior has affective (attitudes) and cognitive aspects (Lind 1985, 11). Neither the behavior nor the attitudes of a person can be split into components. Moreover, Lind, in the 1980s, offered the opinion that (moral) attitudes are nothing more than the moral orientation of a person. Most of the scientific investigations of attitudes towards inclusion refer to the attitudes of teachers, learner students, educators, and parents. The attitudes of children and adolescents have rarely been examined.

The obtained research results pertaining to the relation between attitudes and inclusion are as follows:

1. Attitudes toward inclusion depend on several factors:

- type of disability (Stoiber, Gettinger, \& Goetz 1998; Avramidis \& Kalyva 2007; Kopp 2009; Janz 2012.

- social and cognitive factors, well-founded expert knowledge, possibilities of reflection, multi-professional team structures, human resources (Jordan et al. 2010; Urton et al. 2014)

- experience and good training (Götz, Hauenschild, Greve, \& Hellmers 2015)

2. Attitudes to inclusion directly influence the effectiveness of inclusion efforts (Anderson, Klassen, \& Georgiou 2007; Huber 2011; Jordan, Glenn, \& McGieh-Richmond 2010; Jordan, Schwartz, \& McGiehRichmond 2009; Jordan \& Stanovich 2001; Lindsay 2007; Stanovich \& Jordan 1998; Urton, Wilbert, \& Hennemann 2014).

3. Attitudes of most of students towards peers are neutral (Trauntschnig 2015). 
However, I assume that attitude tests often fail to measure what should be measured. What is often criticized about classical test theory in general, in my opinion also applies to attitude tests:

- These tests can be simulated upwards.

- Some effects (social desirability effects, Halo effect, Hawthorne effects, etc.) that could distort results cannot be excluded.

- A lot of statements on inclusion are not relevant to interviewees. They relate only to queried verbal statements, i.e. to the external standards, but not to the inner attitude of respondents. But actual attitudes-not lip service-are essential for the realization of inclusion.

- Attitude tests regarding inclusion measure aspects that are not clearly defined.

- Attitudes are measured in isolation without any situative context.

Tests which are based on classical test theory define and measure morality [or attitudes towards inclusion] in terms of external standards (...). Otherwise, the test scores can be simulated in every direction (...). Simply asking people about their moral competence [or their attitudes towards inclusion] overwhelms them. Firstly, they often have only a vague idea of their own moral competence [or of their own attitudes towards inclusion]. Secondly, they are tempted to respond in a way which they think is expected from them. Thus, such questions measure more social desirability than moral competence [or genuine internal attitudes towards inclusion] (Lind 2016, 66).

To summarise:

1. Attitudes are aspects and not components of behaviour.

2. A measurement instrument is necessary which is able to measure all these aspects simultaneously.

(...) it is not enough if we only capture (...) [the] moral orientation (attitudes, values, etc.). We must also analyze the relation between attitudes and behavior (Lind 2016, 65).

In my opinion, the debate about attitudes towards inclusion runs in a circle: it is necessary to change the so-called attitudes towards inclusion. But it is very difficult when many people either are not able to and/or do not want to change their attitudes.

Following Tony Booth, I assume that real inclusion means something more:

inclusion means to establish a connection-a connection between our practical action and the values which we have represented for a long time, and which are dormant in us (Booth 2011, 10). 
Booth is one of the authors of the Index for Inclusion, an instrument that can help to determine the next steps for institutions in developing inclusive settings. Institutions that want to install inclusive settings can answer these main questions by using the Index for Inclusion:

1. What do we do?

2. What do we need?

3. What do we want to do in regards to inclusion?

(Klaus Seifried: On the way to the inclusive school. Symposium Inclusion Assistant on 26.06.2017 at the Technical University of Chemnitz)

But in my opinion, it is more crucial to answer the following question first:

"What are we capable of doing?"

What do I mean by that?

\section{Dual-Aspect-Dual-Layer Model}

We get more clarity if we use the Dual-Aspect/Dual-Layer Model by Georg Lind. Lind assumes that the human behavior has a conscious and an unconscious layer. It is not crucial what we reflect about our behavior but how we are really oriented morally and whether we behave corresponding to our moral orientation.

Moral orientation are rules, principles, ideals [attitudes, valuesin my opinion, inclusion itself is an ideal] etc. which guide a person's pattern of behavior (Lind 2015, 180).

Only if we are able to act in accordance with our moral orientation-i.e. in accordance with our inner-favored moral principles or our so-called inner voice, can we behave with moral competence.

[Moral competence] is the ability to solve problems and conflicts on the basis of moral principles through deliberation and discussion instead of violence and deceit (Lind 2016, 13).

\begin{tabular}{rcc}
\hline & Affective aspect & Cognitive aspect \\
\hline $\begin{array}{c}\text { Conscious layer: } \\
\text { Ethical reflection }\end{array}$ & $\begin{array}{c}\text { Articulated ethical } \\
\text { principles }\end{array}$ & $\begin{array}{c}\text { Ethical judgment and } \\
\text { reasoning }\end{array}$ \\
\hline $\begin{array}{c}\text { Unconscious layer: } \\
\text { Overt moral behaviour }\end{array}$ & $\begin{array}{c}\text { Moral } \\
\text { orientation } \\
\text { (Attitudes...) }\end{array}$ & $\begin{array}{c}\text { Moral } \\
\text { competence }\end{array}$ \\
\hline
\end{tabular}

Table 2: The Dual-Aspect/Dual-Layer Model of Moral Self (Lind 2016, 57) 
Let us now have a look at the situation in my Vocational School Centre in this context.

Most of my students favor the higher Kohlberg Stages of moral orientation. This means that most of my students want good for the others. They are, so to speak, morally well-oriented. This implies that their attitudes towards inclusion are presumably also good.

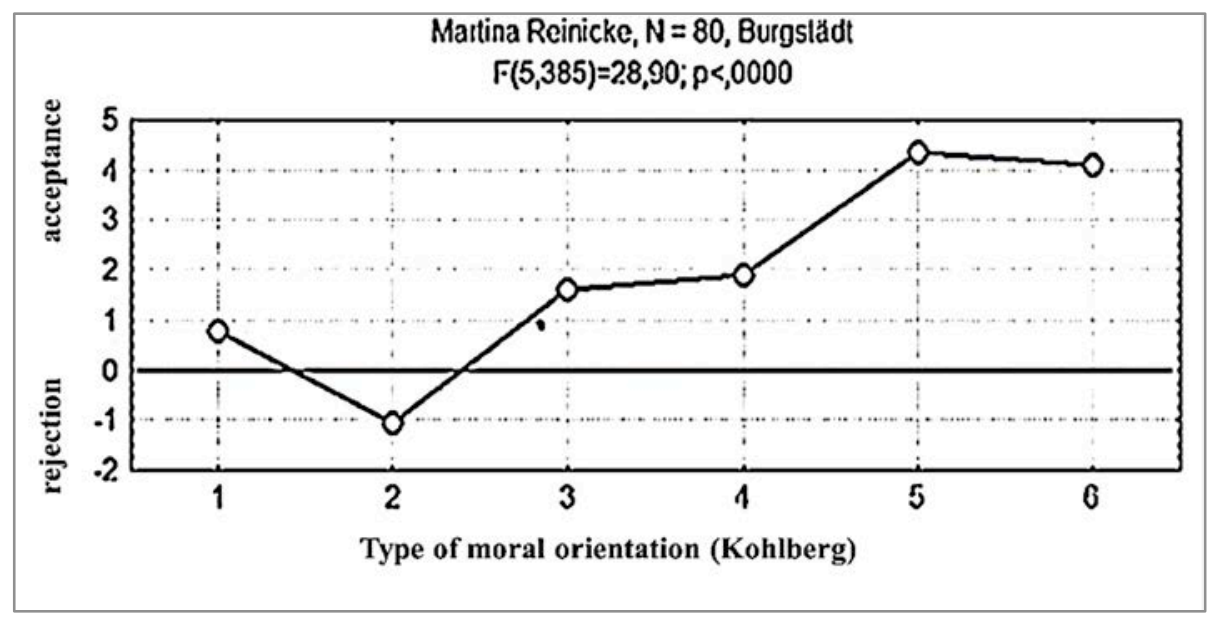

Figure 4: Moral orientation of 80 students of the Vocational School Centre DöbelnMittweida, school location Burgstädt in 2016/2017 (calculated by Georg Lind)

But what is about their moral competence?

Moral competence can be measured with the Moral Competence Test (MCT ${ }^{\circledR}$ ) given by Lind. This experimental questionnaire is an innovative new measurement instrument that allows the measurement of the internal structural dispositions of moral judgment in an objective way.

The MCT produces what is called C-score (...) 'the C stands for competence. The $\mathrm{C}$-score indicates to which degree a participant rates the argument of the test by their moral quality rather than by other factors like opinion agreement (Lind 2016,69).

In a $\mathrm{C}$-score scale of maximum 100 (maximum of moral competence), 82\% of my students have a C-score less than $30 \%$. The average $\mathrm{C}$-score is less than $18 \%$.

As a precondition for successful inclusion, I assume that an inclusive behavior is necessary.

Inclusive behavior is a behavior what shows recognition of both: of diversity of all as well as of the dignity of each individual so 
that no one is excluded and anyone can identify with his or her group. $^{3}$

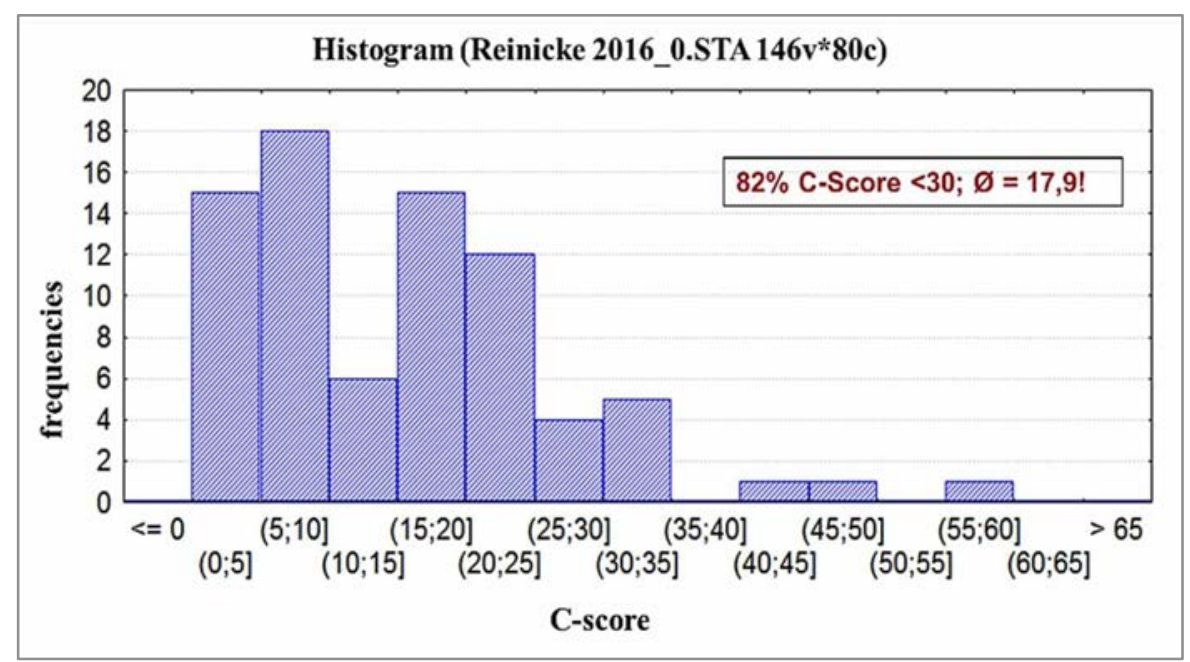

Figure 5: Moral competence of 80 students of the Vocational School Centre DöbelnMittweida, school location Burgstädt in 2016/2017 (calculated by Georg Lind)

In accordance with Lind, I assume that an average C-score of 30 is necessary for this. This C-score is necessary to ensure that participants of inclusion process are able to constantly solve the central conflict of inclusion in both its facets-the conflict between the right to equal participation and the claim to diversity. Consequently, an important relevant factor for inclusion is moral competence.

It is not necessary to change attitudes, as many scholars assume - it is necessary to improve moral competence.

To sum up, it can be said that at present, we are missing the moral basis for inclusion itself as well as for the debate about inclusion.

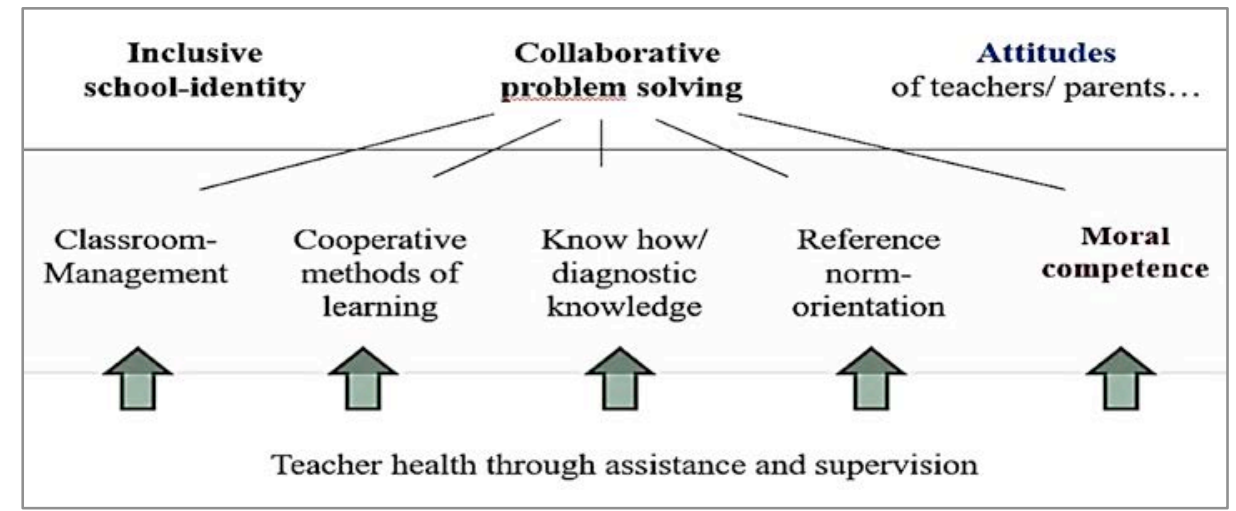

Figure 6: Conditions for success of inclusion

3 Working definition by Martina Reinicke 


\section{Research Project}

Research question and Hypothesis

The following question now arises: Does inclusive behavior depend on moral competence?

I assume that if I carry out two KMDD ${ }^{\circledR}$-sessions annually in diverse classes, the moral competence in those groups will improve. Furthermore, I suppose that an improved moral competence leads to a better inclusive behavior, which in turn leads to the progress of inclusion.

\section{Measurement instruments and variables}

In order to prove this, I measure three variables:

1. Moral Competence, with the above mentioned MCT $^{\circledR}$.

2. Inclusive Behavior: To measure inclusive behaviour, students were asked to answer the following questions with the help of a questionnaire: 'Next to whom would you like to sit?' and 'Next to whom would you not like to sit?' Based on the gained data, I drew and analysed sociograms of several classes. Thus, I was able to determine the following seven indicators: rejection, coherence, cohesion, cliques, alliances, isolation, and centrality 4 .

3. Finally, I measured the Progress of Inclusion by means of an instrument called Inklumat ${ }^{5}$. The Inklumat is an electronic questionnaire based on the aforementioned 'Index for Inclusion'.

\section{Research process}

Prior to all the data collection, I carried out KMDD ${ }^{\circledR}$ sessions in four classes with 16-35-year-old students. The control groups consisted of all the other classes in which I teach ethics, where I had not carried out KMDD ${ }^{\circledR}$ sessions. Apart from this, I measured the C-score and inclusive behavior in classes both with and without KMDDs. Furthermore, I measured the progress of inclusion in a school where $\mathrm{KMDD}^{\circledR}$ was installed and in another school where $\mathrm{KMDD}^{\circledR}$ sessions were not carried out.

\section{Research results}

1. In the class in which I carried out $\mathrm{KMDD}^{\circledR}$ sessions (retailers), the moral competence or the $\mathrm{C}$-score increased more than in the class without KMDDs (social assistants).

\footnotetext{
${ }^{4}$ http://www.babstsoft.com/Soziogramm/soziogramminfo.htm

${ }^{5} \mathrm{http}: / /$ www.inklumat.de/
} 


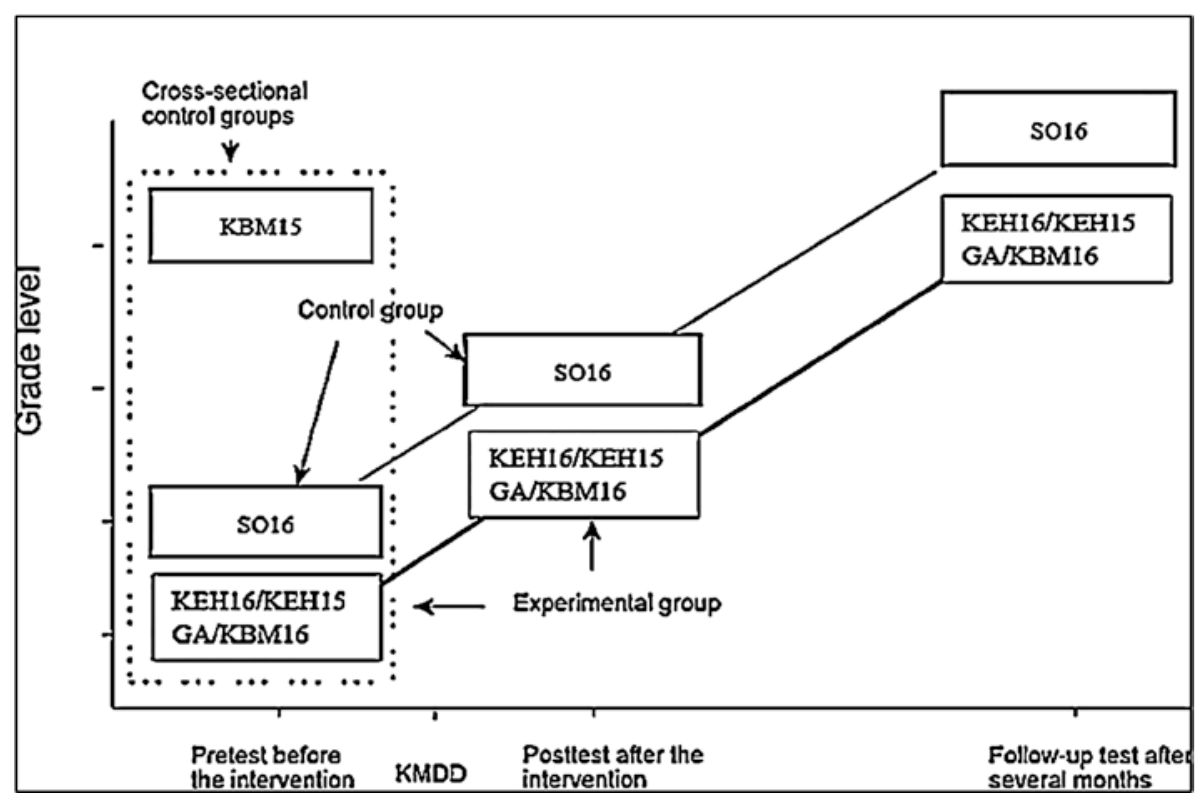

Figure 7: Design of my project during my second certification in the school year 2016/2017

2. The survey with questionnaire, with which we measure the inclusive behaviour of students, shows the following:

a. The class of social assistants (SO16) consists of 22 students (four males, 18 females). The following voting categories regarding the seating arrangement were taken into account: Category 1 (acceptance) and Category 2 (rejection). The number of votes was limited to three in each case. There are clear signs of splitting and disintegration in this class. To be more exact, there are five isolated students, three relatively isolated subgroups with high-level alliance structures, and one negative figure in this class.

b. The group of retailers (KEH16) comprises 17 members (seven males, 10 females). As shown, this class attended three $\mathrm{KMDD}^{\circledR}$ sessions. After these sessions, the survey shows that the indicator of the coherence in this class is average. Furthermore, cohesion in this class is relatively high and increased extremely during the $\mathrm{KMDD}^{\circledR}$ intervention. The mutual rejection is also average. The value of indicator for isolation decreased considerably. In this class, two subgroups exist with a tendency towards isolation. But before introducing of $\mathrm{KMDD}^{\circledR}$, there were four relatively isolated subgroups in this class. Moreover, nine students were non-integrated. After three KMDD sessions, there were one positive and three negatives central figures in this class but no more isolated students. Regarding the indicator 'alliances', it can be said that in this class high-level structures of alliances also exist in subgroups. 


\begin{tabular}{|c|c|c|c|c|c|}
\hline Indicators & 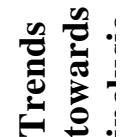 & $\begin{array}{l}\text { SO16 } \\
\text { (withou }\end{array}$ & $\mathbf{K M D D}^{\circledR}$ ) & $\begin{array}{l}\text { KEH16 } \\
\left(1 \times K M D D^{\circledR}\right)\end{array}$ & $\begin{array}{l}\text { KEH16 } \\
(3 \times K M D D \\
\left({ }^{\circledR}\right)\end{array}$ \\
\hline Rejection & & 0,52 & 0,37 & 0,55 & 0,52 \\
\hline Coherence & 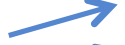 & 0,48 & 0,64 & 0,29 & 0,64 \\
\hline Cohesion & & 0,52 & 0,52 & 0,10 & 0,52 \\
\hline Alliances & & 1,00 & 1,00 & 0,57 & 0,86 \\
\hline Cliques & & 0,93 & 0,86 & 0,87 & 0,86 \\
\hline Isolation & & 0,57 & 0,52 & 0,88 & 0,43 \\
\hline Centrality & & 0,82 & 0,82 & 0,57 & 0,80 \\
\hline
\end{tabular}

Table 2: Development of inclusive behavior in the school year 2016/2017

The results so far show us that the inclusive behavior is better in classes in which $\mathrm{KMDD}^{\circledR}$ sessions are carried out. That is possible in a vocational school. If it is like that, what might be possible if we would foster morality starting with the primary school, from an age of 8 , or even earlier-beginning with kindergarten?

3. Finally, we used the Inklumat for measuring the progress of inclusion. As we used this measurement instrument, we noticed that the school part in which the students periodically had $\mathrm{KMDD}^{\circledR}$ sessions has a better inclusive setting. I exemplarily show only the outcomes of one subcategory: 'Anchoring of values of inclusion'. In my opinion, it is an indication of the success of inclusion efforts with the help of the KMDD® teaching method.

\section{Conclusion}

Inclusion is a dynamic process of continuous conflict solution between the right to equal participation on the one hand and the claim to difference on the other hand. This requires different conditions as well as competencies of all persons involved in education process. However, in addition to the diagnostic competencies of teachers and educators and other "conditions of success", also the establishment of moral education in schools is urgently required. In this context, moral education is not to be understood as education of our pupils and students to better persons. Moral education means to educate children and adolescents to self-conscious people, who are able to represent their opinions openly and honestly as well as in accordance with their actual inner attitudes. Furthermore, our pupils should possess the ability to solve conflicts fair and nonviolent. Only in this way can be arise a behavior with which is respected the dignity of the other- regardless which particularities has someone. 


\section{Outlook}

In the coming years, we seriously have to implement inclusion in Saxony. From the school year 2023/24, children both with and without disabilities will learn together from the first class onwards. For this ambitious goal, the introduction of moral education in schools is urgently needed.

Starting this school year, I will carry out KMDD ${ }^{\circledR}$ sessions at two schools of our school centre. Furthermore, I will continue to compare development of these classes with the development of classes without KMDD ${ }^{\circledR}$.

You can find out more about the KMDD ${ }^{\circledR}$ and the MCT ${ }^{\circledR}$ in Georg Lind's book How To Teach Morality (2016). If you are also interested in the practical application of this theory and in efforts of inclusion at our vocational school centre, feel free to pick up a copy of my book: Moral Competence Reloaded? (2017).

\section{References}

Albers T. et al. 2015. Kitas als Türöffner. Integrative Tageseinrichtungen für Kinder als Schlüssel zur gleichberechtigten Teilhabe. URL: http://www. elterninitiativen-nds-hb.de/fileadmin/user_upload/pdf/kitas_als_ Tueroeffn er_Broschuere.pdf (retrieved on Feb 12, 2018).

Allport G. W. 1935. "Attitudes," in C. Murchison (Ed.), Handbook of Social Psychology. Worcester: Clark University Press.

Anderson C. J. K., Klassen R. M., \& Georgiou G. K. 2007. "Inclusion in Australia: What Teachers Say They Need and What School Psychologists Can Offer." School Psychology International 28:131-147.

Antor G. \& Bleidick U. 2006. Handlexikon der Behindertenpädagogik. Stuttgart: Kohlhammer.

Avramidis E. \& Kalyva E. 2007. "The Influence of Teaching Experience and Professional Development on Greek Teachers' Attitudes Towards Inclusion." European Journal of Special Needs Education 22 (4):367-389. URL: http://eclass.uth.gr/eclass/modules/document/file.php/ SEAC190/3.\%20AVRAMIDIS\%20\%26\%20KALYVA\%20EJSNE\%20 paper\%20final.pdf (retrieved on Oct 09, 2017).

Behindertenrechtskonvention. 2008. URL: https://www.behindertenrechts konvention.info (retrieved on Oct 09, 2017).

Benhabib S. 2008. Die Rechte der anderen. Berlin: Suhrkamp.

Bloom P. 2009. "The Moral Life of Babies." New York Times Magazine, 10 th May.

Booth T. 2011. Wie sollen wir zusammenleben? Frankfurt am Main: Gewerkschaft Erziehung und Wissenschaft.

Booth T. \& Ainscow M. 2003. Index für Inklusion. Trans. to German by I. Boban \& A. Hinz. Martin-Luther-Universität, Halle - Wittenberg. URL: 
http://www. csie.org.uk/resources/translations/IndexGerman.pdf (retrieved on Oct 09,2017 ).

Booth T. \& Ainscow M. 2002. Index for Inclusion. GB. URL: http://www.eenet.org.uk/resources/docs/Index\%20English.pdf (retrieved on Oct 09,2017 ).

Bossaert G. C., Colpin H., Pijl S. J. et al. 2013. „Truly Included? A Literature Study Focusing on the Social Dimension of Inclusion in Education." International Journal of Inclusive Education 17:60-79.

Braun W. \& Forst R. 2014. The Power of Tolerance. A Debate. Ed. by L. Di Blasi \& Ch. Holzhey. New York: Columbia University Press.

Bürli A. 1997. Sonderpädagogik international: Vergleiche, Tendenzen, Perspektiven. FB Erziehungs-, Sozial- und Geisteswissenschaften. Hagen: Fernuniversität-Gesamthochschule.

Celikates R. \& Gosepath S. 2013. Philosophie der Moral. Frankfurt am Main: Suhrkamp.

Comenius J. A. 1657. Große Didaktik. Trans. and ed. by A. Flittner. Stuttgart: Klett-Cotta.

Comenius J. A. 1907. "The Great Didactic." Ed. by M. W. Keatinge. London: Adam and Charles Black. URL: https://archive.org/stream/cu31924031 053709\#page/n11/mode/2up (retrieved on Oct 18, 2017).

Diderot D. 1916. Letter on the Blind for the Use of Those Who See. Trans. and ed. by M. Jourdain. Chicago - London. URL: http://tems. umn.edu/pdf/Diderot-Letters-on-the-Blind-and-the-Deaf.pdf (retrieved on 2017-10-09).

Dyson D. H. 2004. What Do We Really Know About Inclusive Schools? A Systematic Review of the Research Evidence. London: Routledge.

Edelstein W., Oser F., \& Schuster P. (Hrsg.) 2001. Moralische Erziehung in der Schule. Entwicklungspsychologie und pädagogische Praxis. Weinheim: Beltz.

Ellger-Rüttgardt S. 2008. Geschichte der Sonderpädagogik. München: Ernst Reinhardt Verlag.

Ellinger S. \& Stein R. 2012. „Effekte Inklusiver Beschulung: Forschungsstand im Förderschwerpunkt emotionale und soziale Entwicklung." Empirische Sonderpädagogik 4:85-109. URL: http://www.pedocs.de /volltexte/2014/9293/pdf/ESP_2012_2_Ellinger_Stein_Effekte_ inklusiver_Beschulung.pdf (retrieved on Oct 09, 2017).

Ferguson D. 2008. „International Trends in Inclusive Education: The Continuing Challenge to Teach Each One and Everyone." European Journal of Special Needs 23(2):109-120.

Feuser G. 2001. „Prinzipien einer inklusiven Pädagogik“. Behinderte in Familie, Schule und Gesellschaft 24(2):25-29. 
Feuser G. 2012. Thesen Integration. Zürich. URL: http://www.georgfeuser.com/conpresso/_data/Feuser_-_Thesen_Integration_04_2012. pdf (retrieved on Oct 09, 2017).

Feuser G. 2013. Integrative Heilpädagogik-eine Fachdisziplin im Wandel. URL: http://www.georg-feuser.com/conpresso/_data/Feuser__Integrative_Heilpaedagogik_-_Inklusion_Wende_ohne_Wandel_Home page.pdf (retrieved on Oct 09, 2017).

Fishbein M. \& Ajzen I. 1975. Belief, Attitude, Intention and Behavior: An Introduction to Theory and Research. Reading: Addison-Wesley.

Framhein-Peisert G. 1984 „Student und Studium im interkulturellen Vergleich." Klagenfurter Beiträge zur bildungswissenschaftlichen Forschung 14:166-187.

Geißler R. 2004. „Einheit-in-Verschiedenheit. Die interkulturelle Integration von Migranten - ein humaner Mittelweg zwischen Assimilation und Segregation." Berliner Journal für Soziologie 14 (3):287-298.

Götz J., Hauenschild K., Greve W., \& Hellmers S. 2015. „Einstellungen von Lehrerinnen und Lehrern zur inklusiven Grundschule," in D. Blömer, M. Lichtblau, A.-K. Jüttner, K. Koch, M. Krüger, R. Werning, \& R. Berlin (Eds.), Perspektiven auf inklusive Bildung. Wiesbaden: Springer (3439).

Güttler P. O. 1996. Sozialpsychologie. Soziale Einstellungen, Vorurteile, Einstellungsänderungen. München - Wien: Oldenbourg.

Hartung J. 2006. Sozialpsychologie. Stuttgart: Kohlhammer.

Heinrich-Böll-Stiftung. 2012. Dossier Diversität und Kindheit-frühkindliche Bildung, Vielfalt und Inklusion. URL: https://heimatkunde.boell.de/sites/default/files/diversitaet_und_kind heit_kommentierbar.pdf (retrieved on Oct 09, 2017).

Heinrichs K., Oser F., \& Lovat T. (Eds.) 2013. Handbook of Moral Motivation. Theories, Models and Applications. Rotterdam: Sense Publishers.

Hennemann T., Wilbert J., \& Hillenbrand C. 2014. Wissenschaftliche Begleitung im Rahmen der Umsetzung der inklusiven Schule im Kreis Mettmann. Abschlussbericht. URL: https://www.hf.uni-koeln.de/data /e/File/ Abschlussbericht\%20Mettmann.pdf (retrieved on Oct 07, 2017).

Huber C. 2011. Inklusion wirkt?! Ein Forschungsüberblick. Universität zu Köln. URL: https://www.hf.uni-koeln.de/data/e/File/Lehrstuhl\%20ES/Jun.Prof.Dr.ChristianHuber-Inklusionwirkt!-EinForschungsberblick.pdf (retrieved on Oct 09, 2017).

Huber C. 2012. Inklusive Forschung? Handout. Universität zu Köln, Germany. URL: https://www.rhein-erft-kreis.de/stepone/data/downloads/ f7/8b/00/huber2012inklusiveforschunghandout.pdf (retrieved on Oct $09,2017)$. 
Humboldt W. v. 1960. "Theorie der Bildung des Menschen". In K. Giehl \& A. Flintner (Eds.), Humboldt, Werke in fünf Bänden, Bd. 1. Darmstadt: Wissenschaftliche Buchgesellschaft.

Humboldt W. v. 2010. "Briefe an eine Freundin", Brief vom 22.12.1822. Werke in fünf Bänden, Bd. 1, K. Giehl \& A. Flintner (Eds.). Berlin: Wissenschaftliche Buchgesellschaft.

Kegan R. 1994. Die Entwicklungsstufen des Selbst. München: Kindt Verlag.

Keller M. 2005. „Moralentwicklung und moralische Sozialisation,“ in D. Horster, J. Oelkers, D. Horster, \& J. Oelkers (Hrsg.), Pädagogik und Ethik. Wiesbaden: Verlag für Sozialwissenschaften (149-172).

Keller M. 2016. "Kognition, Gefühl und moralisches Selbst." SCHÜLER: Wissen für Lehrer, Heft "Werte" 1:48-51.

Klemm K. \& Preuss-Lausitz U. 2011. "Auf dem Weg zur schulischen Inklusion in Nordrhein-Westfalen. Empfehlungen zur Umsetzung der UNBehindertenrechtskonvention im Bereich der allgemeinen Schulen." URL: http://www.inklusion-olpe.de/wp-content/uploads/NRW_Inkl usionskonzept_2011_-_neue_Version_08_07_11.pdf (retrieved on Oct 09, 2017).

Kohlberg L. 1996. Die Psychologie der Moralentwicklung. Ed. by W. Althof. Berlin: Suhrkamp.

Kruse P. 2015. Next Practice Erfolgreiches Management von Instabilität. Veränderung durch Vernetzung. Offenbach: Gabal Verlag GmbH.

Latzko B. \& Malti T. 2010. Moralische Erziehung und Entwicklung in Kindheit und Adoleszenz. Göttingen: Hogrefe.

Liebers K., Kolke S., \& Schmidt C. 2016. Ausgewählte Ergebnisse aus der wissenschaftlichen Begleitung des Schulversuchs Erina 2012-2015. Leipzig. URL: http://www.schule.sachsen.de/download/download_bildung /16_11_28_erina_Zusammenfassung_Zwischenbefunde.pdf (retrieved on Oct 09, 2017).

Lind G. 1984. "Theorie und Validität des 'Moralisches-Urteil-Tests'-Zur Erfassung kognitiv-struktureller Effekte der Sozialisation," in G. Framhein \& J. Langer (Eds.), Student und Studium im internationalen Vergleich. Klagenfurt: Kärntner Druck- und Verlagsgesellschaft (166-187).

Lind G. 1985. "Inhalt und Struktur des moralischen Urteilens." In Ansätze und Ergebnisse der" Just Community"-Schule. Die Deutsche Schule 1:4-12. http://www.uni-konstanz.de/ag-moral/pdf/Lind-1985_Inhalt-undStruktur.pdf (retrieved on Oct 8, 2017).

Lind G. 1985. "Moralische Urteilskompetenz und berufliche Ausbildung." Konstanz: Universität Konstanz.

Lind G. 2005. "The Cross-Cultural Validity of the Moral Judgment Test (MJT). Confirmation of 17 Cross-Cultural Adaptations." MOSAIC Conference, Konstanz 2005. URL: https://www.uni-konstanz.de/ag- 
moral/pdf/Lind-2005_Cross-cultural-validity-of-the-MJT.pdf (retrieved on Oct 08,2017$)$.

Lind G. 2009. Moral ist lehrbar, Handbuch zu Theorie und Praxis demokratischer Bildung. München: Oldenburg Verlag.

Lind G. 2011. „Moral Education: Building on Ideals and Fostering Competencies". Contemporary Issues in Education 2(1):45-59. URL: http://www.uni-konstanz.de/ag-moral/pdf/Lind-2011_Moral Education_CIE.pdf (retrieved on Oct 08, 2017).

Lind G. 2014. „Moralische Kompetenz und globale Demokratie," in M. Tiedemann \& J. Rohbeck (Eds.), Philosophie und Verständigung in der pluralistischen Gesellschaft. Dresden: Thelem (192-211).

Lind G. 2015. Kurze Beschreibung des Moralischen Kompetenz-Tests (MKT) URL: http://www.uni-konstanz.de/ag-moral/mut/MJT-d-kurz.htm (retrieved on Feb 12, 2018).

Lind G. 2015. Moral ist lehrbar. Berlin: Logos.

Lind G. 2016. Glossary. Konstanz. http://www.uni-konstanz.de/ag-moral/ moral/glossary_engl.htm (retrieved on Oct 09, 2017).

Lind G. 2016. How to Teach Morality. Promoting Deliberation and Discussion, Reducing Violence and Deceit. Berlin: Logos.

Lind G. 2017. Moralerziehung auf den Punkt gebracht. Schwalbach/Ts.: Wochenschau Verlag.

Lind G., Nielsen A., \& Schmidt U. 1979. Moralisches Urteil und Hochschulsozialisation. Konstanz. URL: http://www.uni-konstanz.de/agmoral/pdf/Lind-1976_et-al-Moral-und-Hochschule-AU40.pdf (retrieved on Oct 09,2017 ).

Lindemann H. 2016. „Konstruktion und empirische Validierung eines Instrumentes zur Erfassung der Einstellungen von Schülerinnen und Schülern gegenüber Peers." Empirische Sonderpädagogik 1:5-21. URL: http://www.pedocs.de/volltexte/2016/11851/pdf/ESP_2016_1_Linde mann_Konstruktion_und_empirische_Validierung.pdf (retrieved on Oct 09, 2017).

Muth J. 1986. Integration von Behinderten. Essen: Neue Deutsche Schule Verlagsgesellschaft GmbH. URL: http://bidok.uibk.ac.at/library/muthintegration.html (retrieved on Oct 09, 2017).

Nowak E., Schrader D., \& Zizek B. (Eds.) 2013. Educating Competencies for Democracy. Frankfurt am Main - Bern - New York: Peter Lang.

Nunner-Winkler G. 2009. „Prozesse moralischen Lernens und Entlernens.“ Zeitschrift für Pädagogik 55 (4):528-548.

Piaget J. 1974. Biologie und Erkenntnis. Frankfurt am Main: Fischer.

Piaget J. 1976. „The Affective Unconscious and the Cognitive Unconscious, “ in B. Inhelder \& H. Chipman (Eds.), Piaget and His School. New York: Springer (63-71).

Piaget J. 1979. Das moralische Urteil beim Kinde. Berlin: Suhrkamp. 
Pöhlmann F. 2016. Philosophie: Werke aus drei Jahrtausenden. Stuttgart: J.B. Metzler.

Prengel A. 2014. Inklusion in der Frühpädagogik. Bildungstheoretische, empirische und pädagogische Grundlagen. URL: http://www.weiterbildungs initiative.de/uploads/media/Inklusion_in_der_Fruehpaedagogik_ 5Band_2uebaAuflage_2014_Prengel.pdf (retrieved on Oct 09, 2017).

Preuss-Lausitz U. 2011 (Jan). Gutachten zum Stand und zu den Perspektiven inklusiver sonderpädagogischer Förderung in Sachsen. Dresden - Erfurt - Berlin. URL: http://civ-mitteldeutschland.de/cms/ upload/Aktuelles_und_Termine/Inklusionsgutachten_Sachsen _Endfassung .pdf (retrieved on Oct 09, 2017).

Reinicke M. 2015. „Inclusion As Moral Challenge: The Potential of the Konstanz Method of Dilemma Discussion (KMDD)." Filozofia Publiczna i Edukacja Demokratyczna 4(1):88-101.

Reinicke M. 2017. Moral Competence Reloaded (self-publishing).

Robeck J. 2012. Von der Segregation über Integration zur Inklusion. Frankfurt am Main: Vindobona Verlag.

Sander A. 2004. „Konzepte einer inklusiven Pädagogik.“ Zeitschrift für Heilpädagogik 5:240-244.

Sander A. 2006. Vortrag: Interdisziplinarität in einer inklusiven Pädagogik. Luxemburg. URL: http://www.ances.lu/index.php/arc-bulletin/onlinedokutheik/83-profdr-a-sander-interdisziplinaritaet-in-einerinklusiven-paedagogik (retrieved on oct 10, 2017).

Sander W., Igelbrink C., \& Brüggen F. (Hrsg.) 2014. UrteilsBildung-eine lösbare pädagogische Herausforderung: Theoretische Grundlagen und praktische Hinweise. Berlin: LIT Verlag.

Schillinger M. 2013. „Verifying the Dual-Aspect Theory: A Cross-Cultural Study on Learning Environment and Moral Judgment Competence," in E. Nowak, D. Schrader, \& B. Zizek (Eds.), Educating Competencies for Democracy. Frankfurt am Main - Bern - New York: Peter Lang (23-46).

Schmidt C., Kolke S., \& Liebers K. 2015 (Feb 26). Schulversuch ERINAErgebnisse aus dem 2. Schulversuchsjahr. Sachsen, Germany. URL: http://www.hszg.de/fileadmin/Redakteure/Projekte/zint/Präsentatio n_ERINA_26_02_2015.pdf (retrieved on Oct 10, 2017).

Schür S. 2010. „Inklusion und Diversity Management - Perspektiven einer Pädagogik für alle Kinder." Zeitschrift für Inklusion-online.net. URL: http://www.inklusion-online.net/index.php/inklusion-online/article /view/125/125 (retrieved on Oct 09, 2017).

Six B. 2000. spektrum.de. URL: http://www.spektrum.de/lexikon/ psychologie/einstellungen/3914 (retrieved on Oct 09, 2017).

SMK. 2000. Die Sächsische Konzeption zur Integration von Migranten. URL: https://www.revosax.sachsen.de/vorschrift/9651-Konzeption-zurIntegration-von-Migranten\#x1 (retrieved on Oct 09, 2017). 
Speck 0. 2010. Schulische Inklusion aus heilpädagogischer Sicht. Rhetorik und Realität. München: Ernst Reinhardt Verlag.

Stangl W. 2017. Online Lexikon. Enzyklopädie für Psychologie und Pädagogik. Österreich. URL: http://lexikon.stangl.eu/alphabetischesinhaltsverzeichnis/ (retrieved on Jan 06, 2017).

Stanovich J. P., Jordan A. \& Perrot J. 1998. "Relative Differences in Academic Self Concepts and Peer Acceptance among Students in Inclusive Classrooms." Remedial \& Special Education 9 (2): 120-6.

Stoiber K., Gettinger M., \& Goetz D. 1998. "Exploring Factors Influencing Parents' and Early Childhood Practitioners' Beliefs about Inclusion." Early Childhood Research Quarterly 13 (1):107-124.

Trauntschnig M. 2015. "Einstellung von SchülerInnen gegenüber Peers mitunterschiedlichen Beeinträchtigungen sowie gegenüber Peers mit Migrationshintergrund," in S. Schwab \& P. Watko (Eds.), Ausschnitte aus der Grazer Inklusionsforschung - Empirische Forschungsprojekte in der Inklusiven Pädagogik, Bd. 2. Hamburg: Verlag Dr. Kovač (29-47).

Triandis H. C. 1975. "Culture Training, Cognitive Complexity and Interpersonal Attitudes", in R. Brislin et al. (Eds.), Cross Cultural Perspectives on Learning. New York: Sage.

UNESCO 2016. "Education 2030_Framework for Action. Declaration." Incheon. URL: //www.unesco.de/fileadmin/medien/Dokumente/Bildung/ Framework_for_Action_ED-2016.pdf (retrieved on Oct 09, 2017).

Urton K., Wilbert J., \& Hennemann T. 2014. "Der Zusammenhang zwischen der Einstellung zur Integration und der Selbstwirksamkeit von Schulleitungen und deren Kollegien." Empirische Pädagogik 6 (1):3-16.

Wocken H. 2009. Inklusion \& Integration. Frankfurt am Main. URL: http://www.inklusion20.de/material/inklusion/Inklusion\%20vs\%20I ntegration_Wocken.pdf (retrieved on Oct 09, 2017).

Zizek B., Garz D., \& Nowak E. (Eds.) 2015. Kohlberg Revisited. Rotterdam - Taipei: Sense Publishers. 


\title{
Martina Reinicke (Döbeln-Mittweida)
}

Inclusion and Moral Competence.

Hypotheses about Two Closely Related Tasks of the School ${ }^{6}$

\begin{abstract}
In my article, I will give a short historical overview of inclusionresearch. The focus lies on relation between moral and inclusion. I will introduce three branches of inclusion research and deduce my definition of inclusion from it. Inclusion can be understood as a dynamic process of realizing of equal participation on the one hand and of entitlement to diversity on the other hand. That means, inclusion lives from the solution of its immanent conflictthe conflict between equality and diversity. Therefore, I assume that "the ability to solve problems and conflicts on the basis of universal moral principles by means of deliberation and discussion, instead of using violence, deceit and coercion, or more specifically... the ability to judge arguments in regard to their moral quality instead of their opinion-agreement" (Lind 2016) is urgently needed. This ability is an important precondition for realizing inclusion. Following educational theory of morality by Lind and others, it's not necessary to change the moral attitudes (moral orientation) in persons that are involved in the process of inclusion. It's more important to improve their inclusive ability and their inclusive behavior. Inclusive behavior means a behavior with which shows recognition of both: of diversity of all as well as of the dignity of each individual. On this theoretical basis, I furthermore want to introduce a little research project carried out by the author in Vocational School Centre. The aim of this project was to improve the inclusive behavior by using the Konstanz Method of Dilemma Discussion ${ }^{\circledR}$.
\end{abstract}

Keywords: inclusion, inclusive behaviour, moral education, moral competence

Ethics in Progress (ISSN 2084-9257). Vol. 8 (2017). No. 2, Art. \#2, pp. 5-27.

Creative Commons BY-SA 3.0

Doi: 10.14746/eip.2017.2.2

6 Paper presented at the International Conference "Moral Competence: A brand new research topic", September 29th-30th 2017, at Adam Mickiewicz University, Poznan, Poland. 